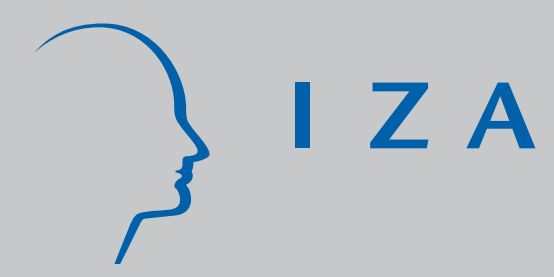

IZA DP No. 3972

The Impact of Being Monitored on Discriminatory Behavior among Employers: Evidence from a Natural Experiment

Magnus Carlsson

Dan-Olof Rooth

J anuary 2009 


\title{
The Impact of Being Monitored on Discriminatory Behavior among Employers: Evidence from a Natural Experiment
}

\author{
Magnus Carlsson \\ Kalmar University \\ Dan-Olof Rooth \\ Kalmar University, \\ CReAM and IZA \\ Discussion Paper No. 3972 \\ January 2009 \\ IZA \\ P.O. Box 7240 \\ 53072 Bonn \\ Germany \\ Phone: +49-228-3894-0 \\ Fax: +49-228-3894-180 \\ E-mail: iza@iza.org
}

Any opinions expressed here are those of the author(s) and not those of IZA. Research published in this series may include views on policy, but the institute itself takes no institutional policy positions.

The Institute for the Study of Labor (IZA) in Bonn is a local and virtual international research center and a place of communication between science, politics and business. IZA is an independent nonprofit organization supported by Deutsche Post Foundation. The center is associated with the University of Bonn and offers a stimulating research environment through its international network, workshops and conferences, data service, project support, research visits and doctoral program. IZA engages in (i) original and internationally competitive research in all fields of labor economics, (ii) development of policy concepts, and (iii) dissemination of research results and concepts to the interested public.

IZA Discussion Papers often represent preliminary work and are circulated to encourage discussion. Citation of such a paper should account for its provisional character. A revised version may be available directly from the author. 


\section{ABSTRACT}

\section{The Impact of Being Monitored on Discriminatory Behavior among Employers: Evidence from a Natural Experiment ${ }^{*}$}

Today there is a variation within the EU to what extent nations allow for situation test results to constitute mass of evidence in court in order to prevent ethnic discrimination. In the UK The Equality and Human Rights Commission has the right to conduct discrimination tests and to even prosecute firms, implying that discriminating firms face the risk of a significant penalty. Other European countries have been reluctant to use such tests as a tool for counteracting discrimination and discuss a much softer version with only monitoring. In this study two labor market field experiments, sending qualitatively identical job applications with randomly assigned Swedish and Middle Eastern sounding names to employers, show that ethnic discrimination exists in hiring in the Swedish labor market. In both studies extensive media coverage occurred when being only halfway finished informing employers of their hiring practices being monitored by such situation testing. This study utilizes these unique events and the data from the experiments to perform a difference-in-differences analysis of whether discrimination decreased after the media coverage. The results reveal no sign of employers changing their hiring practices when being aware of running the risk of being included in such an experiment. This suggests that the detection risk alone is not sufficient if authorities wish to use field experiments as a discrimination prevention strategy. Instead, it must be combined with some penalty to become effective.

JEL Classification: J64, J71

Keywords: ethnic discrimination, correspondence testing, situation testing, field experiments

Corresponding author:

Dan-Olof Rooth

Department of Economics

Kalmar University College

39182 Kalmar

Sweden

E-mail: Dan-Olof.Rooth@hik.se

\footnotetext{
*A research grant from the Swedish Council for Working Life and Social Research is gratefully acknowledged.
} 


\section{Introduction}

A substantial literature on the existence of ethnic discrimination in the labor market has emerged since Becker's (1957) pioneering work on the economics of discrimination. A much lesser strand of literature has focused on what policies prevent ethnic discrimination to occur. ${ }^{1}$ Recently, a renewed interest has occurred within the EU to use so called situation tests to hinder ethnic discrimination and to enforce anti-discrimination legislation. Such tests vary somewhat in design but basically imply setting up a situation where, in this case, an employer is being presented with fictional job applicants, some of whom possess a characteristic which may incite discriminatory behavior, without the employer suspecting being observed.

Today, the judicial system in several European countries; such as Belgium, Czech Republic, France, Hungary, Slovakia, and the UK, allows for situation test results to constitute mass of evidence in court. ${ }^{2}$ In the extreme case, The Equality and Human Rights Commission in the UK has the right to conduct discrimination tests and to even prosecute firms. ${ }^{3}$ Hence, discriminating firms operating in the UK face the risk of a significant penalty. Other European countries, as Sweden, have been reluctant to use such tests as a tool for counteracting discrimination and discuss a much softer version with only monitoring. However, this stand has little to do with actual limitations in the judical system. In 2005 law students initiated lawsuits against night clubs based on situation tests of ethnic discrimination. Since some of these night clubs were later convicted, also the judicial system in Sweden accepts situation test results as testimony.

This is the first study to analyze whether employers become less discriminatory when running the risk of being monitored by situation testing in the labor market, even if no clear

\footnotetext{
${ }^{1}$ One example is the work on affirmative action policies used in the US, see Altonji and Blank (1999) and the references therein.

${ }^{2}$ See European Commission, 2006. This is also the case in the US.

${ }^{3}$ In the US, the Equal Employment Opportunity Commission has developed a testing methodology and a procedure how to enforce civil rights.
} 
defined penalty is associated. Our strategy for identifying the effect of being monitored by a situation test on employers' discriminatory behavior is to utilize two random and unique events which interrupted the data collection of two previous situation test experiments in hiring: Carlsson and Rooth (2007 and 2008). Both of these studies were inferred, being only halfway finished, by excessive media coverage about situation testing in the Swedish labor market. Hence, after the media coverage employers advertising for labor should be aware of the possibility of being included in a situation testing experiment. ${ }^{4}$ Moreover, the media coverage was unforeseen, making it random which employers were exposed and which employers were not.

The situation test experiment used involve sending two qualitatively identical fictitious job applications to employers advertising for labor - the only difference being the name of the applicant, which signals group belonging. The degree of discrimination is then quantified by calculating the difference in the probability of being invited to an interview for the two groups. The main advantage of the method is that, by construction, the researcher is guaranteed to observe the same characteristics of the applicant as the employer, and any difference in the probability of being invited to a job interview must be because of employers acting on the name of the applicant when hiring.

The next section describes the method used, while the results are presented in Section 3, followed by the conclusion in Section 4 .

\section{Methods}

\section{The field experiments}

The data was taken from two previous field experiments measuring the extent of ethnic discrimination in Sweden: Carlsson and Rooth (2007, Experiment A) and Carlsson and Rooth

\footnotetext{
${ }^{4}$ We find this quite likely since a clear majority of about a hundred firms/recruiters that we contacted knew of these situation tests being conducted.
} 
(2008, Experiment B). In these experiments, the job applications belonged to young native males with identical levels of qualifications within occupations - the only difference being the names attached to the application: either a typical Swedish sounding name or a typical Middle Eastern sounding name.

Experiment A was conducted between May 2005 and February 2006. During this time period job advertisements for selected occupations (see below) found at the Swedish Employment Agency’s webpage were applied to - each employer receiving one application with a Swedish sounding name and one with a Middle Eastern sounding name. In total, 3,228 applications were sent to 1,614 employers. The callback rate for a job interview were 28.6 percent for applicants with a Swedish sounding name and 19.0 percent for applicants with a Middle Eastern sounding name, a statistically significant difference of 9.6 percentage points.

In the case of Experiment B, data was collected between August 2006 and April 2007, following a similar procedure as in Experiment A. In total 2,628 applications were sent to 1,324 employers advertising for labor at the Swedish Employment agency's webpage. In this experiment the callback rate for an interview was 41.5 percent for applicants with a Swedish sounding name and 24.4 percent for applicants with a Middle Eastern sounding name, a statistically significant difference of 17.1 percentage points. ${ }^{5}$

In the end thirteen different occupations were used: computer professionals, business sales, four categories of teachers, accountants, nursing, construction, restaurants, shop sales, motor-vehicle drivers and cleaning. ${ }^{6}$ Hence, this set of occupations included both skilled and semi/unskilled occupations. Although the complete labor market was not analyzed, we applied to all vacant jobs found on the webpage within the chosen occupations.

\footnotetext{
${ }^{5}$ The explanation for the higher callback rate in Experiment B is that the applicants in this experiment had higher levels of qualifications compared to in Experiment A.

${ }^{6}$ Experiment B did not include the cleaners and teachers (language) occupations. The experiments were restricted to the two major cities of Sweden: Stockholm and Gothenburg.
} 


\section{The media coverage}

On two occasions did the media report that large scale field experiments measuring employer discrimination were to be conducted, see Table A1 in the appendix. Regarding Experiment A, the headline on the front page of Text-TV on the $16^{\text {th }}$ of September 2005 was that authorities intend to send fictitious job applications to employers for measuring ethnic discrimination. ${ }^{7}$ Hence, this event occurred right in the middle of the data collection. Furthermore, between the 16 th and $22^{\text {nd }}$ of September three out of nine newspapers with the largest circulation in Sweden, including the largest daily morning paper, Dagens Nyheter, published similar articles as headline news, and so did at least fourteen other local newspapers.

Turning to Experiment B, on the $5^{\text {th }}$ of November 2006 the headline in Dagens Nyheter was "Employers discriminate against Arabic names”, referring to the results in Carlsson and Rooth (2007). Altogether at least seven of the nine largest newspapers published articles about the subject during the following days. Also, at least five local newspapers and other media reported about the topic. In this case too, the media attention occurred in the middle of the data collection.

Even if the media coverage in the last experiment did not explicitly state that a new experiment was to be carried out, it should have the same effect since employers then again became aware of running the risk of being included in a such experiments.

\section{Results}

In this section we analyze the impact of the media coverage, which occurred during Experiment A and B, using the difference-in-differences (DD) estimator. The DD estimate is easily calculated as the difference in the probability of being invited to an interview for applicants with a Middle Eastern sounding name after and before the media coverage minus

\footnotetext{
${ }^{7} 2.8$ million daily readers of a Swedish total population of approximately 9 million.
} 
the corresponding difference for the applicants with a Swedish sounding name. In other words, it is the difference in the time effects across the two groups that constitute the DD estimate. The DD estimate is obtained using the linear regression equation:

$$
y=\beta_{0}+\beta_{1} T+\beta_{2} M+\beta_{3}\left[T^{*} M\right]+\varepsilon
$$

In this model, $y$ equals one if the applicant was invited for a job interview, being zero otherwise, $T$ equals zero if the job was applied to before the media coverage and one if it was applied to after the media coverage, $M$ equals zero for applicants with a Swedish sounding name and one for applicants with a Middle Eastern sounding name, while $\beta_{0}, \beta_{1}$, and $\beta_{2}$ gives the corresponding parameters. The parameter of the interaction term $\left[T^{*} M\right], \beta_{3}$, provides the DD-estimate of interest.

Unconditional on any covariates (Model 1) there is no evidence of monitoring having an impact on the callback rate of minority applicants, see the third row of Table 1 . The DD estimate is virtually equal to zero in both experiments and the result is not altered when occupation fixed effects (Model 2) or additional firm characteristics (male share in workforce, if male recruiter, and number of employees, Model 3) are added to Model 1. Furthermore, the results in Table 1 show no evidence of a time trend in the callback rate for interview for the majority either (see the estimate of $\beta_{1}$ in the first row). Finally, irrespective of the media coverage, having a typical Middle Eastern sounding name, as opposed to a typical Swedish sounding name, implies a ten and twenty percentage points lower probability of being invited for a job interview in Experiment $\mathrm{A}$ and $\mathrm{B}$, respectively (see the estimate of $\beta_{2}$ in the second row).

\footnotetext{
*** Table 1 about here $* * *$
} 
Although not finding any support for an effect of monitoring on the callback rate for a job interview there could nonetheless exist an impact in specific occupations or at the regional level. Therefore, Model 1 was re-estimated on each occupation separately, for only low/high skilled occupations, and separately for the Stockholm and Gothenburg labor market areas, see Table A2 and A3 in the appendix. The results from these estimations confirm the findings at the aggregated level.

Before turning to the conclusions a sensitivity check of the DD model is appropriate. Suppose, for example, that there was a negative trend in the relative employment chances among applicants with a Middle Eastern sounding name and that the media coverage broke this trend. Such a mechanism would not appear in the results above. To some extent we have studied this issue by dividing the pre-media-coverage period into two equal time periods and then performed a "fake" DD type of analysis without finding any indications of a time trend in receiving a callback for interview.

\section{Discussion}

The callback rate for a job interview for applicants with a Middle Eastern name did not increase after employers being informed about running the risk of being monitored on ethnic discrimination by authorities using situation testing. The policy implications of this result concerns the use of discrimination tests to enforce anti-discrimination legislation. Although being discussed in some EU countries, it appears to date be an open question whether discrimination tests will be a part of the EU 's anti-discrimination measures in the future. In this respect our results clearly suggest that if EU authorities were to implement a discrimination prevention strategy using situation tests it should be associated with a credible threat of a penalty for discriminating employers, which is the case in the UK. Only being aware of being monitored is not sufficient for employers to change behavior. 


\section{References}

Altonji, J., and Blank, R. (1999) Race and Gender in the Labor Market. In Ashenfelter O, Card D (eds) Handbook of Labor Economics, 3143-3259. Elsevier. Amsterdam.

Carlsson, M. and Rooth, D (2007), "Evidence of Ethnic Discrimination in the Swedish Labor Market using Experimental Data”, Labour Economics, Vol. 14, Issue 4, p. 716-729.

Carlsson, M. and Rooth, D. (2008), "Is it Your Foreign Name or Foreign Qualifications? - An Experimental Study of Ethnic Discrimination in Hiring”, IZA DP\#3810, Bonn.

European Commission (2006) "European Anti-Discrimination Law Review”, Issue No. 3, Brussels.

Gary S. Becker (1957). The Economics of Discrimination. Chicago, University of Chicago Press. 


\section{Appendix}

Table A1. The extent of media coverage during the field experiments

Media

Circulation

Experiment A Experiment B

Largest Daily Newspapers Circulated

in the Major Cities of Sweden

\begin{tabular}{|c|c|c|c|}
\hline Aftonbladet & 416500 & & Yes \\
\hline Dagens Nyheter & 347100 & Yes & Yes \\
\hline Expressen & $326300^{*}$ & & Yes \\
\hline GT & $326300^{*}$ & & Yes \\
\hline Kvällsposten & $326300 *$ & & Yes \\
\hline Göteborgs-Posten & 242700 & & \\
\hline Svenska Dagbladet & 193500 & & Yes \\
\hline Sydsvenskan & 123200 & Yes & \\
\hline Dagens Industri & 117800 & Yes & Yes \\
\hline \multicolumn{4}{|c|}{ s in Stockholm and Gothenburg } \\
\hline Stockholm City & 297700 & & Yes \\
\hline Metro, Stockholm & 280800 & & \\
\hline Metro, Göteborg & 102100 & & \\
\hline Text-TV & $2800000^{\star \star}$ & Yes & \\
\hline
\end{tabular}

$\underline{\text { Other Local Media - Experiment A }}$

Other Local Media - Experiment B

\section{ST Press}

Arbetarbladet

Lärarnas Tidning

Hotellrevyn

Vestmanlands Läns Tidning

SR Sörmland

Uppsala Nya Tidning

SVT.se Nyheter

Bohuslänningen

Västerbottens-Kuriren

Gefle Dagblad

Ljusnan

Sundsvalls Tidning

Borås Tidning

Helsingborgs Dagblad

Borlänge Tidning

Falukuriren

Södra Dalarnes Tidning

Nya Ludvika Tidning

Notes: This table reports media coverage as daily circulation in the case of newspapers and as the number of readers in the case of Text-TV. For newspapers marked with $(*)$, the sum of the total circulation for these newspapers is given. Source: Svensk Dagspress 2007 and www.svt.se/texttv 
Table A2. Effect on the probability of an invitation to interview.

\begin{tabular}{|c|c|c|c|c|}
\hline & $\begin{array}{l}\text { High } \\
\text { Skilled } \\
(1)\end{array}$ & $\begin{array}{l}\text { Low } \\
\text { Skilled } \\
(2)\end{array}$ & $\begin{array}{c}\text { Stockholm } \\
\text { (3) }\end{array}$ & $\begin{array}{c}\text { Gothenburg } \\
\text { (4) }\end{array}$ \\
\hline \multicolumn{5}{|c|}{ Experiment $\mathrm{A}$} \\
\hline After & $\begin{array}{c}0.01 \\
{[0.03]}\end{array}$ & $\begin{array}{c}-0.03 \\
{[0.02]}\end{array}$ & $\begin{array}{c}0.01 \\
{[0.02]}\end{array}$ & $\begin{array}{l}-0.09^{\star} \\
{[0.05]}\end{array}$ \\
\hline Middle Eastern name & $\begin{array}{c}-0.10^{\star \star \star} \\
{[0.03]}\end{array}$ & $\begin{array}{c}-0.10^{\star \star \star} \\
{[0.02]}\end{array}$ & $\begin{array}{l}-0.09^{\star \star \star} \\
{[0.02]}\end{array}$ & $\begin{array}{c}-0.19^{\star \star \star} \\
{[0.05]}\end{array}$ \\
\hline After * Middle Eastern name & $\begin{array}{l}-0.01 \\
{[0.03]}\end{array}$ & $\begin{array}{c}0.01 \\
{[0.03]}\end{array}$ & $\begin{array}{l}-0.01 \\
{[0.02]}\end{array}$ & $\begin{array}{c}0.08 \\
{[0.06]}\end{array}$ \\
\hline Occupational fixed effects & Yes & Yes & Yes & Yes \\
\hline $\mathrm{N}$ & 1,584 & 1,644 & 2,432 & 796 \\
\hline \multicolumn{5}{|c|}{ Experiment $\mathrm{B}$} \\
\hline After & $\begin{array}{c}0.02 \\
{[0.04]}\end{array}$ & $\begin{array}{c}-0.02 \\
{[0.03]}\end{array}$ & $\begin{array}{c}0.00 \\
{[0.03]}\end{array}$ & $\begin{array}{c}0.00 \\
{[0.06]}\end{array}$ \\
\hline Middle Eastern name & $\begin{array}{c}-0.18^{\star \star \star} \\
{[0.03]}\end{array}$ & $\begin{array}{c}-0.20^{\star \star \star} \\
{[0.03]}\end{array}$ & $\begin{array}{c}-0.21^{\star \star \star} \\
{[0.02]}\end{array}$ & $\begin{array}{c}-0.13^{\star \star *} \\
{[0.05]}\end{array}$ \\
\hline After * Middle Eastern name & $\begin{array}{c}0.02 \\
{[0.04]}\end{array}$ & $\begin{array}{c}0.03 \\
{[0.04]}\end{array}$ & $\begin{array}{c}0.04 \\
{[0.03]}\end{array}$ & $\begin{array}{l}-0.03 \\
{[0.06]}\end{array}$ \\
\hline Occupational fixed effects & Yes & Yes & Yes & Yes \\
\hline $\mathrm{N}$ & 1,260 & 1,368 & 2,124 & 504 \\
\hline \multicolumn{5}{|c|}{$\begin{array}{l}\text { Notes: This table reports the effect on the callback rate for interview (from estimated Linear Probability } \\
\text { Models). Each column, for Experiment A and B respectively, reports the effect on the callback rate of } \\
\text { applying after the media coverage, having a typical Middle Eastern name and the interaction effect of the } \\
\text { two, which is DD-estimator. The models are estimated separately for } 1 \text { ) high skilled occupations, 2) low } \\
\text { skilled occupations, 3) Stockholm and 4) Gothenburg respectively. }{ }^{* *} \text {, and } * * * \text { denote the ten, five and } \\
\text { one percent significance level, respectively. Reported standard errors (in brackets) are adjusted for } \\
\text { clustering on workplace. }\end{array}$} \\
\hline
\end{tabular}


Table A3. Effect on the probability of an invitation to interview.

\begin{tabular}{|c|c|c|c|c|c|c|c|c|c|c|c|c|}
\hline & \multirow[b]{2}{*}{$\begin{array}{c}\text { Accountants } \\
\text { (1) }\end{array}$} & \multirow[b]{2}{*}{$\begin{array}{l}\text { Business } \\
\text { Sales } \\
\text { Assistants } \\
(2) \\
\end{array}$} & \multirow[b]{2}{*}{$\begin{array}{c}\text { Computer } \\
\text { Professionals } \\
(4) \\
\end{array}$} & \multirow[b]{2}{*}{$\begin{array}{c}\text { Construction } \\
\text { Workers }{ }^{\dagger \dagger} \\
(5)\end{array}$} & \multirow[b]{2}{*}{$\begin{array}{c}\text { Motor } \\
\text { Vehicle } \\
\text { Drivers } \\
(7) \\
\end{array}$} & \multirow[b]{2}{*}{$\begin{array}{c}\text { Nurses } \\
(8)\end{array}$} & \multirow[b]{2}{*}{$\begin{array}{c}\text { Preschool } \\
\text { Teachers } \\
(9) \\
\end{array}$} & \multirow[b]{2}{*}{$\begin{array}{c}\text { Restaurant } \\
\text { Workers } \\
(10)\end{array}$} & \multirow[b]{2}{*}{$\begin{array}{c}\text { Shop } \\
\text { Sales } \\
\text { Assistants } \\
(11)\end{array}$} & \multicolumn{3}{|c|}{ Teachers } \\
\hline & & & & & & & & & & $\begin{array}{l}\text { Upper } \\
\text { Sec. } \\
\text { School } \\
(12) \\
\end{array}$ & $\begin{array}{c}\text { Language }^{\dagger} \\
(13)\end{array}$ & $\begin{array}{c}\text { Math/ } \\
\text { Science }^{\dagger+\dagger} \\
(14) \\
\end{array}$ \\
\hline & \multicolumn{12}{|c|}{ Experiment $\mathrm{A}$} \\
\hline After & $\begin{array}{l}-0.03 \\
{[0.04]}\end{array}$ & $\begin{array}{c}0.01 \\
{[0.05]}\end{array}$ & $\begin{array}{c}0.12 \\
{[0.08]}\end{array}$ & & $\begin{array}{l}-0.02 \\
{[0.07]}\end{array}$ & $\begin{array}{l}-0.07 \\
{[0.07]}\end{array}$ & $\begin{array}{l}0.15^{\star *} \\
{[0.07]}\end{array}$ & $\begin{array}{c}0.03 \\
{[0.03]}\end{array}$ & $\begin{array}{l}-0.01 \\
{[0.03]}\end{array}$ & $\begin{array}{c}0.05 \\
{[0.11]}\end{array}$ & $\begin{array}{l}-0.25^{\star} \\
{[0.14]}\end{array}$ & $\begin{array}{c}0.00 \\
{[0.17]}\end{array}$ \\
\hline Middle Eastern & -0.05 & $-0.07^{*}$ & 0.11 & & $-0.12^{\star \star}$ & $-0.07^{*}$ & $-0.18^{\star \star \star}$ & -0.05 & $-0.09 * \star$ & -0.09 & $-0.33^{\star *}$ & -0.14 \\
\hline & {$[0.03]$} & {$[0.04]$} & {$[0.09]$} & & {$[0.05]$} & {$[0.04]$} & {$[0.06]$} & {$[0.05]$} & {$[0.04]$} & {$[0.07]$} & {$[0.16]$} & {$[0.09]$} \\
\hline After * & 0.04 & -0.01 & -0.16 & & -0.08 & -0.08 & 0.03 & 0.00 & -0.02 & -0.14 & 0.17 & 0.04 \\
\hline Middle Eastern & {$[0.06]$} & {$[0.05]$} & {$[0.09]$} & & {$[0.07]$} & {$[0.06]$} & {$[0.07]$} & {$[0.05]$} & {$[0.05]$} & {$[0.09]$} & {$[0.20]$} & {$[0.13]$} \\
\hline \multirow[t]{2}{*}{$\mathrm{N}$} & 372 & 556 & 212 & & 156 & 300 & 368 & 280 & 400 & 128 & 120 & 84 \\
\hline & \multicolumn{12}{|c|}{ Experiment B } \\
\hline After & $\begin{array}{c}0.07 \\
{[0.07]}\end{array}$ & $\begin{array}{c}0.04 \\
{[0.06]}\end{array}$ & $\begin{array}{l}-0.01 \\
{[0.12]}\end{array}$ & $\begin{array}{c}0.06 \\
{[0.24]}\end{array}$ & $\begin{array}{l}-0.13 \\
{[0.10]}\end{array}$ & $\begin{array}{c}0.04 \\
{[0.08]}\end{array}$ & $\begin{array}{c}0.01 \\
{[0.07]}\end{array}$ & $\begin{array}{l}-0.05 \\
{[0.06]}\end{array}$ & $\begin{array}{l}-0.02 \\
{[0.04]}\end{array}$ & $\begin{array}{l}-0.04 \\
{[0.15]}\end{array}$ & & \\
\hline Middle Eastern & $\begin{array}{c}-0.21^{\star \star \star} \\
{[0.06]}\end{array}$ & $\begin{array}{c}-0.16^{\star \star \star} \\
{[0.04]}\end{array}$ & $\begin{array}{c}-0.24^{\star \star \star} \\
{[0.07]}\end{array}$ & $\begin{array}{c}-0.30^{\star \star \star} \\
{[0.08]}\end{array}$ & $\begin{array}{c}-0.24^{\star \star \star} \\
{[0.07]}\end{array}$ & $\begin{array}{l}-0.13^{\star *} \\
{[0.06]}\end{array}$ & $\begin{array}{l}-0.10^{\star *} \\
{[0.05]}\end{array}$ & $\begin{array}{l}-0.18^{\star *} \\
{[0.07]}\end{array}$ & $\begin{array}{c}-0.15^{\star \star \star} \\
{[0.05]}\end{array}$ & $\begin{array}{l}-0.20^{*} \\
{[0.10]}\end{array}$ & & \\
\hline After * & 0.07 & 0.01 & 0.02 & 0.09 & 0.02 & -0.07 & -0.01 & 0.03 & -0.01 & 0.08 & & \\
\hline Middle Eastern & {$[0.08]$} & {$[0.06]$} & [0.12] & {$[0.24]$} & [0.12] & {$[0.07]$} & {$[0.07]$} & {$[0.09]$} & {$[0.06]$} & {$[0.15]$} & & \\
\hline $\mathrm{N}$ & 276 & 516 & 156 & 96 & 156 & 300 & 372 & 300 & 300 & 96 & & \\
\hline
\end{tabular}

Notes: This table is similar to Table A2 but divides data on the occupational level. The Cleaners occupation is not included in Experiment B. In Experiment A, being after the media coverage predicts perfect failure for the Cleaners occupation. $(\dagger)$ The Teachers (Language) occupation was not included in Experiment B. ( $\dagger \dagger$ ) In the case of Construction Workers in Experiment A, there are only three observations before the media coverage. (†††) In the case of Teachers (Math/Science) in Experiment B, there are only three observations after the media coverage. 


\section{Tables}

Table 1. The impact on the callback rate for interview.

\begin{tabular}{lcccccccc}
\hline & \multicolumn{3}{c}{ Experiment $\mathrm{A}$} & & \multicolumn{3}{c}{ Experiment B } \\
\cline { 2 - 5 } \cline { 6 - 8 } & $(1)$ & $(2)$ & $(3)$ & & $(1)$ & $(2)$ & $(3)$ \\
\hline After media coverage & 0.00 & -0.01 & -0.01 & & -0.01 & -0.01 & $-0,03$ \\
& {$[0.02]$} & {$[0.02]$} & {$[0.02]$} & & {$[0.03]$} & {$[0.03]$} & {$[0.03]$} \\
Middle Eastern sounding name & $-0.10^{\star \star \star}$ & $-0.10^{\star \star \star}$ & $-0.11^{\star \star \star}$ & & $-0.19^{\star \star \star}$ & $-0.20^{\star \star \star}$ & $-0.20^{\star \star \star}$ \\
& {$[0.02]$} & {$[0.02]$} & {$[0.02]$} & & {$[0.02]$} & {$[0.02]$} & {$[0.02]$} \\
After media coverage* Middle Eastern sounding name & 0.00 & 0.00 & 0.02 & & 0.03 & 0.03 & 0.03 \\
& {$[0.02]$} & {$[0.02]$} & {$[0.02]$} & & {$[0.03]$} & {$[0.03]$} & {$[0.03]$} \\
Occupational fixed effects & No & Yes & No & & No & Yes & No \\
Firm characteristics controls & No & No & Yes & & No & No & Yes \\
$\mathrm{N}$ & 3,228 & 3,228 & 2,996 & & 2,628 & 2,628 & 2,136 \\
\hline
\end{tabular}

Notes: This table reports the effect on the callback rate for interview. Model 1 reports the effect on the callback rate of applying after the media coverage, having a Middle Eastern sounding name and the interaction effect of the two, which is the DD-estimator. Model 2 and 3 are identical to Model 1 but with occupational fixed effects and firm characteristics added. *, **, and *** denote the ten, five and one percent significance level, respectively. Reported standard errors (in brackets) are adjusted for clustering on workplace. 